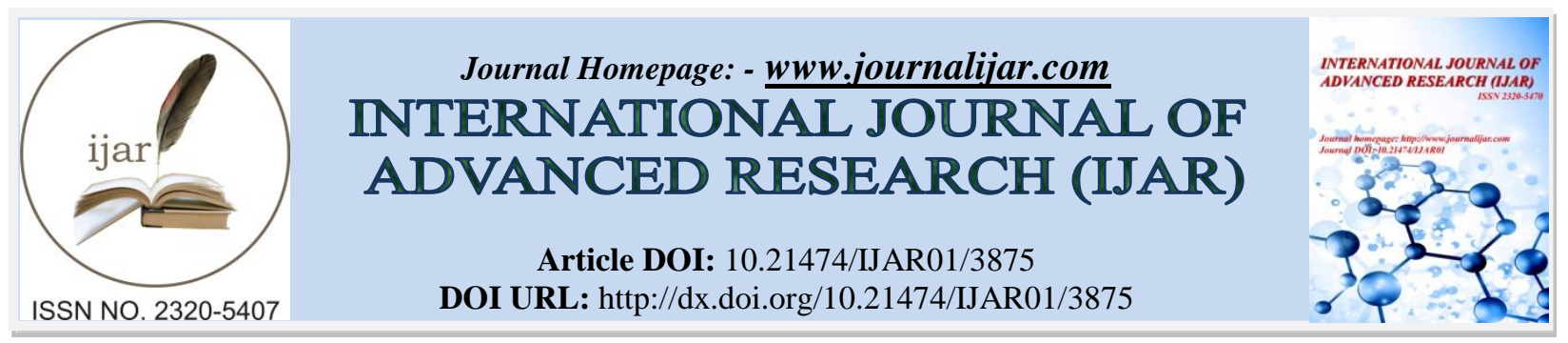

RESEARCH ARTICLE

\title{
PHARMACOLOGICAL STUDY OF AERIAL PARTS OF TWO MALVACEOUS PLANTS.
}

Dr. Rekha Tripathi.

Maharaja Surajmal Institute of Technology,New Delhi-110058, India.

\section{Manuscript Info}

Manuscript History

Received: 12 February 2017

Final Accepted: 14 March 2017

Published: April 2017

Key words:-

Hibiscus micranthus, Abutilon bidentatum, Aerial parts, Ethanolic extract, Antimicrobial activity.

\begin{abstract}
The present study deals with the pharmacological studies of ethanolic extract of aerial parts of two Malvaceous plants : Hibiscus micranthus Linn. and Abutilon bidentatum Hochst. The ethanolic extracts of aerial parts of plants were examined for antibacterial and antifungal studies by using Disc diffusion method. Escherichia coli, Klebsiella aerogenes, Proteus vulgaris and Pseudomonas aeruginosa as Gram ve and Staphylococcus aureus as Gram +ve bacteria were selected for antibacterial efficacy and Aspergillus flavus, Aspergillus niger, Fusarium moniliforme and Rhizoctonia bataticola fungi were selected for antifungal efficacy. In case of antibacterial efficacy, the ethanolic extract of $\mathrm{H}$. micrathus did not exhibit any activity against selected bacteria but A. bidentatum exhibited trace activity against $S$. aureus and in case of antifungal efficacy, extract of both the plants inhibited growth of almost all the test fungi. Out of selected fungi, the growth of $F$. moniliforme inhibited the most by ethanolic extract (aerial parts) of both the plants.
\end{abstract}

\section{Introduction:-}

Medicinal plants are the nature's gift to human being to make disease free healthy life. The medicinal importance of plant(s), attracted the attention of chemists to study the natural products. Plant products are being increasingly tried upon and utilized for various purposes in the field of pharmaceuticals. It is believed that the extracts and products of plants being natural, are harmless to human beings and their environment. The present work was, therefore, undertaken with the antimicrobial studies of two plants belongs to family Malveceae . The genus Hibiscus comprises about 46 species , 20 of which are found in India and some of these are found to be medicinally very important (Chopra et al., 1971; I.C.M.R.,1987 ; Yoganarsimhan et al.,1979). H. micrathus is a herb growing in the hotter parts of India. It is used as a febrifuge (Kirtikar et al.,1975). In India certain parts of Gujarat, the fruits and flowers of this plant are used as hypoglycemic agent (Kakrani et al.,2005). The plant has been scientifically validated for its antipyretic, anti-inflammatory, hematological effects (Al-yahya et al., 1987) . A survey of literature revealed that no work on the antimicrobial studies is reported so far. The genus Abutilon comprises mainly of shrubs and small trees. About 10 species are found in India, some of which are found to be medicinally useful. A. indicam have several applications in medicinal world(Chopra et al., 1971; Kirtikar et al.,1975 ; Sinha et al.,1985 ; Sharma et al., 1989). A. bidentatum is a shrub growing throughout the hotter parts of India .A perusal of literature revealed that this plant remained unexplored by the pharmacologists but their sister species have been found to possess promising activity of one type or another. The ethanolic extracts of aerial parts of both the plants were examined for selected test bacteria and test fungi. 


\section{Material and Methods:- \\ Plant Materials:-}

The plant material (aerial parts) of H. micranthus Linn. and A. bidentatum Hochst. were collected from the campus university of Rajasthan, Jaipur and were identified for authenticity in the department of botany, University of Rajasthan, Jaipur (Herbarium sheet No. RUBL 754 and 824 respectively ).

\section{Extraction:-}

Powdered aerial parts of both the plants were extracted on a steam bath for 8 X $3 \mathrm{hrs}$. with ethanol separately. Later, each of these extract was filtered, the residue re-extracted $(2 \mathrm{X})$ for complete exhaustion, the extracts were pooled individually and concentrated under reduced pressure and stored in dark colored bottle at $4^{0} \mathrm{C}$ in a refrigerator.

\section{Sources of Test Organisms:-}

Bacteria:- Pure culture of all test organisms, namely Escherichia coli, Klebsiella aerogenes, Proteus vulgaris and Pseudomonas aeruginosa as Gram -ve and Staphylococcus aureus as Gram +ve bacteria, the human pathogens were obtained through the courtesy of SMS Medical College, Jaipur, which were maintained on Nutrient Broth Medium.

Fungi:- The pure cultures of test fungi, namely Aspergillus flavus, Aspergillus niger, Fusarium moniliforme and Rhizoctonia bataticola were obtained from the Seed Pathology Laboratory, Department of Botany, University of Rajasthan, Jaipur, which were maintained on Potato Dextrose Agar (PDA) medium.

\section{Culture of Test Microbes:-}

For the cultivation of bacteria, Nutrient Broth Medium (NBM) was prepared using 8\% Nutrient Broth (Difco) in distilled water and agar-agar and sterilized at $15 \mathrm{Ibs}$ for 25-30 min. The agar test plates were prepared by pouring $15 \mathrm{ml}$ of NBM into the petri-dishes $(10 \mathrm{~mm})$ under aseptic conditions. The peptone saline solution was prepared (by mixing $3.56 \mathrm{~g} \mathrm{KH}_{2} \mathrm{PO}_{4}+7.23 \mathrm{~g} \mathrm{NaH}_{2} \mathrm{PO}_{4}+4.30 \mathrm{~g} \mathrm{NaCI}+1.00 \mathrm{~g}$ peptone in $1000 \mathrm{ml}$ distilled water, followed by autoclaving) and the bacterial cultures were maintained on this medium by regular sub-culturing and incubation at $37^{\circ} \mathrm{C}$ for $24 \mathrm{hrs}$.

However, for the cultivation of fungi, Potato Dextrose Agar (PDA) medium was prepared by mixing $1000 \mathrm{ml}$ potato infusion prepared from $200 \mathrm{~g}$ potatoes, $20 \mathrm{~g}$ agar and $20 \mathrm{~g}$ glucose, followed by autoclaving; the test fungi were incubated at $27^{\circ} \mathrm{C}$ for $48 \mathrm{hrs}$ and the cultures were maintained on the same medium by regular sub-culturing.

To prepare the test plates, in both bacteria and fungi, $10-15 \mathrm{ml}$ of the respective medium was poured into the petridishes and used for screening.

For assessing the bactericidal efficacy, a fresh suspension of the test bacteria was prepared in saline solution from a freshly grown agar slant, while for fungicidal efficacy, a uniform spread of the test fungi was made using sterile swab.

\section{Bactericidal and fungicidal Assay:-}

For both bactericidal and fungicidal assays Disc diffusion method (Gould et al.,1952) was adopted, because of reproductivity and precision. The different test organisms were preceded separately using a sterile swab over previously sterilized culture medium plates and the zone of inhibition were measured around sterilized dried discs of Whatman No. 1 paper ( $6 \mathrm{~mm}$ in diameter), which were containing $500 \mu \mathrm{g}$ and $1000 \mu \mathrm{g}$ of the test extracts and control amikacin $(10 \mu \mathrm{g} / \mathrm{ml})$ or mycostatin $(100 \mathrm{units} / \mathrm{ml})$ as reference drugs separately. These plates were initially placed at low temperature for $1 \mathrm{~h}$, so as to allow the maximum diffusion of the compound from the discs into the agar plate and later, incubated at $37^{\circ} \mathrm{C}$ for $24 \mathrm{~h}$ in case of bacteria and $48 \mathrm{~h}$ for fungi, after which the zones of inhibition could be easily observed. 
Table 1:- Bactericidal activity of selected plants.

\begin{tabular}{|c|c|c|c|c|c|c|c|c|c|c|c|}
\hline \multirow[t]{2}{*}{ Plant species } & \multirow{2}{*}{$\begin{array}{l}\text { Dose } \\
\mu \mathrm{g} / \text { disc }\end{array}$} & \multicolumn{2}{|c|}{ E.coli } & \multicolumn{2}{|c|}{ K.aerogenes } & \multicolumn{2}{|c|}{ P.vulgaris } & \multicolumn{2}{|c|}{ P. arruginosa } & \multicolumn{2}{|c|}{ S. aureus } \\
\hline & & $\mathrm{IZ}^{*}$ & $\mathrm{AI}^{*}$ & $\mathrm{IZ}$ & $\mathrm{AI}$ & $\mathrm{IZ}$ & $\mathrm{AI}$ & $\mathrm{IZ}$ & AI & $\mathrm{IZ}$ & $\mathrm{AI}$ \\
\hline \multirow{2}{*}{$\begin{array}{l}\mathrm{H} . \\
\text { micranthus }\end{array}$} & 1000 & - & - & - & - & - & - & - & - & \pm & - \\
\hline & 500 & - & - & - & - & - & - & - & - & \pm & - \\
\hline \multirow{2}{*}{$\begin{array}{l}\text { A. } \\
\text { bidentatum }\end{array}$} & 1000 & - & - & - & - & - & - & - & - & \pm & - \\
\hline & 500 & - & - & - & - & - & - & - & - & - & - \\
\hline
\end{tabular}

IZ : inhibition zone (in $\mathrm{mm}$ ) including the diameter of disc $(6 \mathrm{~mm})$

AI : activity index $=($ inhibition zone of sample/inhibition zone of standard

Standard : Amikacin $=10 \mu \mathrm{g} / \mathrm{ml}$.

( \pm ) Trace activity: ( - ) No activity

Table 2:-Fungicidal activity of selected plants.

\begin{tabular}{|c|c|c|c|c|c|c|c|c|c|}
\hline $\begin{array}{l}\text { Plant } \\
\text { species }\end{array}$ & $\begin{array}{l}\text { Dose } \\
\mu \mathrm{g} / \mathrm{disc}\end{array}$ & \multicolumn{2}{|c|}{ A. flavus } & \multicolumn{2}{|c|}{ A. niger } & \multicolumn{2}{|c|}{ F. moniliforme } & \multicolumn{2}{|c|}{ R. bataticola } \\
\hline & & $\mathrm{IZ}^{*}$ & $\mathrm{AI}^{*}$ & IZ & AI & IZ & AI & IZ & $\mathrm{AI}$ \\
\hline \multirow{2}{*}{$\begin{array}{l}\mathrm{H} . \\
\text { micranthus }\end{array}$} & 1000 & 11.00 & 0.50 & 11.00 & 0.48 & 13.00 & 0.57 & 10.00 & 0.41 \\
\hline & 500 & 9.00 & 0.41 & 7.00 & 0.30 & 10.00 & 0.43 & 7.00 & 0.32 \\
\hline \multirow{2}{*}{$\begin{array}{l}\text { A. } \\
\text { bidentatum }\end{array}$} & 1000 & 11.00 & 0.50 & 12.00 & 0.52 & 17.00 & 0.74 & - & - \\
\hline & 500 & 6.00 & 0.27 & 8.00 & 0.35 & 14.00 & 0.61 & - & - \\
\hline
\end{tabular}

IZ: inhibition zone (in $\mathrm{mm}$ ) including the diameter of disc $(6 \mathrm{~mm})$

activity index $=($ inhibition zone of sample/inhibition zone of standard

Standard : Mycostatin $=100$ units/disc .

\section{Result and Discussion:-}

In case of bactericidal activity ethanolic extract of aerial parts of both the plants failed to demonstrate any significant activity against any test bacteria except trace activity against S.aureus. H. micranthus showed activity at both concentrations ( $1000 \mu \mathrm{g} / \mathrm{disc}$ and $500 \mu \mathrm{g} /$ disc) while A. bidentatum exhibited activity only at $1000 \mu \mathrm{g} / \mathrm{disc}$. Table 1 . In case of fungicidal efficacy, both the extracts showed maximum activity against $F$. moniliforme . In comparison, A. bidentatum is more active ( $\mathrm{IZ}=17 \mathrm{~mm}$ at $1000 \mu \mathrm{g} / \mathrm{disc}, \mathrm{IZ}=14 \mathrm{~mm}$ at $500 \mu \mathrm{g} / \mathrm{disc}$ ) than $\mathrm{H}$. micranthus ( $\mathrm{IZ}=13$ $\mathrm{mm}$ at $1000 \mu \mathrm{g} / \mathrm{disc}, \mathrm{IZ}=10 \mathrm{~mm}$ at $500 \mu \mathrm{g} / \mathrm{disc}$ ) against this test fungi. On the other hand, ethanolic extract of aerial parts of $\mathrm{H}$. micrathus demonstrated antifungal activity against $R$. bataticola $(\mathrm{IZ}=10 \mathrm{~mm}$ at $1000 \mu \mathrm{g} / \mathrm{disc}$, $\mathrm{IZ}=7 \mathrm{~mm}$ at $500 \mu \mathrm{g} /$ disc ) while A. bidentatum failed to exhibit any activity against this test fungi. Table 2 .

\section{Conclusion:-}

The present investigation revealed that both the Malvaceous plants are potentially against fungi and can be used as safe and harmless antifungal agents.

\section{Acknowledgement:-}

The author is thankful to Sawai Man Singh (SMS) Hospital, Jaipur and Department of Botany , University of Rajasthan , Jaipur for providing the tested microorganisms for antimicrobial activity.

\section{References:-}

1. Chopra R.N. , Nayar S.L., Chopra I.C. (1971) . Glossary of Indian medicinal plants . 133.

2. I.C.M.R. ( 1987). Medicinal plants of India .2 (24)

3. Yoganarsimhan S. N., Bhat A.V., Toguhashi V.S. ( 1979). Medicinal plants from Mysore district, Karnataka. Indian drugs pharmaceut . Ind. 14 ( 1): 7

4. Kirtikar K.R., Basu B.D. (1975) Indian medicinal plants .1:327.

5. Kakrani H.N., Kakrani B.H., SalujaA.K.(2005).Traditional treatment of diabetes through herbs in Kutch disirct, Gujrat state. Planta Indica .1:16.

6. Al-yahya M.A., Tariq M., Parmar N.S., Ageel A.M.(1987). Pharmacological investigations of Hibiscus micranthus Linn., a febrifuge used in Saudi Arabian folk medicine . Phytother Res.1(2): 73 . 
7. Sinha S.K.P , Dogra J.V.V .(1985) .A Survey of the Plants of Bhagalpur and Santhal Pargana for Saponin, Flavonoids and Alkaloids .Int. J. Crude Drug Res., 23(2) :77 .

8. Sharma P.V, Ahmad Z.A.(1989) .Two Sesquiterpene lactones from Abutilon indicum. Phytochemistry,28(12): 3525 .

9. Gould J.C., Bowie J.H. (1952). The determination of bacterial sensitivity to antibiotics . Edinb. Med. J. 59,: 178. 